\title{
Pyrigemmula, a novel hyphomycete genus on grapevine and tree bark
}

\author{
Donát Magyar • Robert A. Shoemaker • János Bobvos • \\ Pedro W. Crous • Johannes Z. Groenewald
}

Received: 9 June 2010 /Revised: 13 August 2010/Accepted: 24 August 2010 /Published online: 17 September 2010

(C) The Author(s) 2010 This article is published with open access at Springerlink.com

\begin{abstract}
The anamorphic taxon Pyrigemmula aurantiaca gen. et sp. nov. is described and illustrated from specimens that were collected from the inner bark of living woody hosts (Vitis vinifera, Pyrus communis, Mespilus germanica, Platanus hybrida, Elaeagnus angustifolia) and plant debris in Hungary. The fungus is generically distinct in the nature of the pyriform, golden conidiogenous cell with a solitary terminal pore and the ellipsoidal, distoseptate, phragmoconidia that germinate from each end and that have a rarely noted internal hilum quite unlike the hilum of the conidiogenous cell. The new fungus is compared with the type species of a number of allied genera of hyphomycetes. Free spores of the fungus were trapped in air, honeydew sap and rainwater samples. Aerobiological studies showed that the spores are infrequent in the air, whereas their concentration increased with higher atmospheric pressure. Pyrigemmula
\end{abstract}

Taxonomic novelties Pyrigemmula D. Magyar \& R. Shoemaker, gen. nov., Pyrigemmula aurantiaca D. Magyar \& R. Shoemaker, sp. nov.

\footnotetext{
D. Magyar $(\bowtie) \cdot J$. Bobvos

Department of Aerobiological Monitoring,

National Institute of Environmental Health,

P.O. Box 839, Budapest, 1437, Hungary

e-mail: magyar.donat@gmail.com

R. A. Shoemaker

Biodiversity (Mycology and Botany),

Agriculture and Agri-Food Canada,

960 Carling Avenue,

Ottawa, K1A 0C6 ON, Canada

e-mail: shoemakerb@agr.gc.ca

P. W. Crous $\cdot$ J. Z. Groenewald

CBS-KNAW Fungal Biodiversity Centre,

Uppsalalaan 8,

3584 CT Utrecht, The Netherlands

J. Z. Groenewald

e-mail: e.groenewald@cbs.knaw.nl
}

aurantiaca lives in bark fissures and rarely becomes airborne and the spores are mainly dispersed by rain splash.

Keywords Bark · Corticolous · Dematiaceous hyphomycete $\cdot$ Dispersal $\cdot$ Honeydew sap

\section{Introduction}

Stems and branches of woody hosts such as grapevines and fruit trees have in recent years been shown to share the same range of fungi, which are able to migrate between these different hosts (Mostert et al. 2005, 2006; Damm et al. 2007, 2008a, b, 2010; Essakhi et al. 2008). This movement of fungal organisms is usually enhanced by the fact that vineyards are frequently planted adjacent to fruit tree orchards. Upon closer examination, many of these fungi are associated with symptoms of brown wood discoloration, although several appear to simply be endophytic or saprobic (Van Niekerk et al. 2004; Mostert et al. 2006). These include several hyphomycetes such as Phaeomoniella (Petri disease in grapevines, and brown wood streaking in fruit trees; Mostert et al. 2006; Damm et al. 2008a), Phaeoacremonium/ Togninia (brown wood streaking; Mostert et al. 2006; Essakhi et al. 2008), Coniochaeta/Lecythophora (endophytes on various substrates, but also pathogens of humans, and associated with food spoilage; Damm et al. 2010), Collophora (brown wood streaking; Damm et al. 2010), Calosphaeria and Jattaea species (endophytic in wood and bark; Damm et al. 2008a). Several coelomycetous species have also been found to share these hosts, namely species of Paraconiothyrium (endophytic, plant pathogenic; Damm et al. 2008b), and members of the Botryosphaeriaceae (endophytic, plant pathogenic; Slippers et al. 2007; Phillips et al. 2008), to name but a few. Some of these species have proven 
sexual states or synanamorphs, which enable them to survive under different environmental conditions (Crous et al. 2006b), or to have different modes of dispersal, including insects (Mostert et al. 2006), air and rainwater (Magyar et al. 2009). Most of these genera are, however, typical inhabitants of wood and bark, occurring on a broad spectrum of trees and shrubs worldwide (Schoch et al. 2009; Zhang et al. 2009).

During a survey of alternative hosts of grapevine trunk disease pathogens, an unusual hyphomycetous fungus was found on bark and in honeydew samples of various woody hosts. Based on these findings, aerobiological studies were undertaken to understand its mode of dispersal. Furthermore, the fungus was isolated in pure culture, and is subsequently described here as a novel hyphomycete genus and species. It is contrasted to members of a number of other hyphomycete genera, from which we believe it to be distinct.

\section{Materials and methods}

\section{Isolation}

During investigations of bark-inhabiting fungi of living grapevines and a variety of trees, pieces of bark were collected in different locations in Hungary. The samples were incubated in moist chambers at room temperature in the laboratory and examined after 3-5 days. Monospore isolates were initiated from colonies found on the bark of Elaeagnus angustifolia and Vitis vinifera. The resulting colonies sporulated on synthetic nutrient-poor agar (SNA) at $25^{\circ} \mathrm{C}$, but not on malt extract agar (MEA) (Crous et al. 2009b). All isolates were slow-growing. Small pieces of agar with the colonies of the fungus were placed on sterile filter paper and autoclaved bark of Elaeagnus angustifolia and Vitis vinifera. Dishes were incubated in a moist chamber for 2 weeks at $25^{\circ} \mathrm{C}$ to induce improved sporulation to facilitate morphological description. Digital photomicrographs were taken with an Olympus BX-51 microscope at $\times 800$ magnification. Fungal structures were mounted on glass slides with clear lactic acid for microscopic examination. Thirty measurements per relevant microscopic structure were determined, with extremes given in parentheses. Colony colours were determined using the colour charts of Rayner (1970) after 7 days at $25^{\circ} \mathrm{C}$ on the bench. Reference strains are maintained in the culture collection of the Centraalbureau voor Schimmelcultures (CBS-KNAW), Utrecht, the Netherlands. Nomenclatural novelties and descriptions were deposited in MycoBank (www.MycoBank.org; Crous et al. 2004).

Spore sampling

The characteristic conidia of the unknown fungus were previously observed during different surveys when data on the occurrence of free spores in air, rainwater and stem sap samples were collected. Air samples were obtained using two 7-day recording air samplers (Hirst 1952; VPPS 2000; Lanzoni, Bologna, Italy). The first trap operated to coincide with the blooming period of grape vines in Italy (May-June): 27 May to 13 June 1994; from 5 June to 3 July 1995; and from 13-24 June 1996, at $12 \mathrm{~m}$ height, in a vineyard (approximately 2,500,000 $\mathrm{m}^{2}$, kept by the Luganotti Company) near the city of Brufa (Central Italy). The second sampler was located at $150 \mathrm{~cm}$ above ground level, in the experimental field of the Plant Protection Institute of the Hungarian Academy of Sciences in Nagykovácsi, where air sampling was conducted between 30 June 2007 and 16 October 2007. The spore trap worked continuously, aspirating air at a rate of $10 \mathrm{l} / \mathrm{min}$. The airborne fungal spores impacted on a tape (MELINEX $^{\circledR}$ strip) coated with a thin adhesive layer (silicone oil). The greased tape was mounted on a rotating drum within the trap, rotating $2 \mathrm{~mm} / \mathrm{h}$. The exposed tape was removed weekly and cut into $48 \mathrm{~mm}$ segments, thus representing $24 \mathrm{~h}$ periods. The segments were placed on microscope slides and stained with basic fuchsin in mounting medium (glycerinejelly). In the air samples, 12 transverse traverses were scanned at $\times 400$ magnification of an Olympus BX 51 microscope.

The technique to prepare honey-sap samples was: $10 \mathrm{~g}$ were taken from $500 \mathrm{~g}$ of previously homogenised honey, dissolved in $20 \mathrm{ml}$ of distilled water at $40^{\circ} \mathrm{C}$, centrifuged for $5 \mathrm{~s}$ at $2,500 \mathrm{~g}$ and allowed to settle. The sediment was recovered in $10 \mathrm{ml}$ of distilled water and again centrifuged. The sediment was then collected with a Pasteur pipette and dried onto microscope slides at $40^{\circ} \mathrm{C}$. It was then mounted in glycerine-gelatine and covered (Louveaux et al. 1978). The entire surface of each preparation was scanned under a microscope and fungal spores were identified. A total of 83 of these samples were examined from Croatia, Greece, Hungary, Italy, Mexico, New Zealand, Portugal, Slovakia, South Africa, Spain, and Tanzania.

Stem-flow rainwater samples were occasionally collected from living trees (24 samples in 2003 and 2004), and from a water-filled tree hollow on a maple tree (Acer platanoides; 65 samples collected between 18 July 2003 and 5 September 2007) in Budapest, Hungary. Depending on the intensity of rainfall, various quantities of water could be collected (2$10 \mathrm{ml}$ ) in centrifuge tubes. One $\mathrm{ml}$ of FAA (50\% ethanol $5 \%$ glacial acetic acid, 10\% formaldehyde) was added for each sample (Ingold 1975). Water samples were settled, then one drop of the sediment was mounted on a microscope slide and allowed to dry. Lactophenol with cotton blue was added to the dried sediment to prepare the sample for further studies.

\section{Biometeorology}

To clarify the connection between spore counts and meteorological variables, a weather station (Weather Station 
WS-3600; Conrad Electronic, Hirschau, Germany) was placed in the vicinity of the sampling site in Hungary. The daily records of temperature $\left({ }^{\circ} \mathrm{C}\right)$, dew point $\left({ }^{\circ} \mathrm{C}\right)$, and relative humidity were measured with a hygrothermometer. Rainfall (mm) and the duration of precipitation (min) were recorded with a rain gauge. An anemometer and an electronic barometer were used to measure wind speed $\left(\mathrm{m} \mathrm{s}^{-1}\right)$, wind direction, and atmospheric pressure $(\mathrm{Pa})$, respectively. To study the effect of meteorological factors (temperature, rain, atmospheric pressure) on the airborne dispersal of the fungus, a logit regression model was used (Statistica, StatSoft). Spore counts were reduced to presence and absence data, because of the low airborne concentration of the spores.

\section{Molecular phylogeny}

Genomic DNA was isolated from fungal mycelium grown on MEA, using the UltraCleanTM Microbial DNA Isolation Kit (MoBio Laboratories, Solana Beach, CA, USA) according to the manufacturer's protocols. Part of the nuclear rDNA operon spanning the 3' end of the $18 \mathrm{~S}$ nrRNA gene (SSU), the internal transcribed spacer 1, the 5.8 S nrRNA gene, the internal transcribed spacer 2 (ITS) and the first 900 bases at the 5' end of the $28 \mathrm{~S}$ nrRNA gene (LSU) was amplified and sequenced as described in Frank et al. (2010). The primers ITS4 (White et al. 1990) and LR0R (Rehner and Samuels 1994) were used as internal sequence primers to ensure good quality sequences over the entire length of the amplicon. Sequences were compared with the sequences available in NCBI's GenBank nucleotide (nr) database using a megablast search and results are discussed below in the species notes. The sequence alignment and subsequent phylogenetic analysis using PAUP v. $4.0 \mathrm{~b} 10$ (Swofford 2003) followed the methods of Crous et al. (2006a, 2009a). Alignment gaps were treated as new character states for the parsimony analysis. Novel sequence data were deposited in NCBI's GenBank database (CBS 126743: GenBank HM241692, CBS 126744: GenBank HM241693; GenBank accessions span the ITS region and the first 900 bases at the 5' end of the $28 \mathrm{~S}$ nrRNA gene).

\section{Results}

Phylogenetic analysis

Approximately 1,500 bases, spanning the ITS and LSU regions, were obtained for the two isolates sequenced. The LSU region was used in the phylogenetic analysis for the generic placement (Fig. 1) and ITS to identify possible species-level relationships in NCBI's GenBank database.

The manually adjusted LSU alignment contained 41 taxa (including the outgroup sequence) and, of the 841 characters (including alignment gaps) used in the phylogenetic analysis, 254 were parsimony-informative, 61 were variable and parsimony-uninformative and 526 were constant. Five equally most parsimonious trees were retained from the heuristic search, the first of which is shown in Fig. $1(\mathrm{TL}=10,78, \mathrm{CI}=0.456, \mathrm{RI}=0.680, \mathrm{RC}=$ $0.310)$. The obtained phylogenetic tree places the isolates in the Chaetosphaeriaceae, with the closest sister species being Ellisembia brachypus and Lecythothecium duriligni. The ITS sequences did not reveal any close hits during the blast search and the isolates are therefore described as a novel genus and species below.

\section{Taxonomy}

Pyrigemmula D. Magyar \& R. Shoemaker, gen. nov.

MycoBank MB 517148

Etymology Pyrum, L. and gemmula L. referring to the pear-shaped conidiogenous cells.

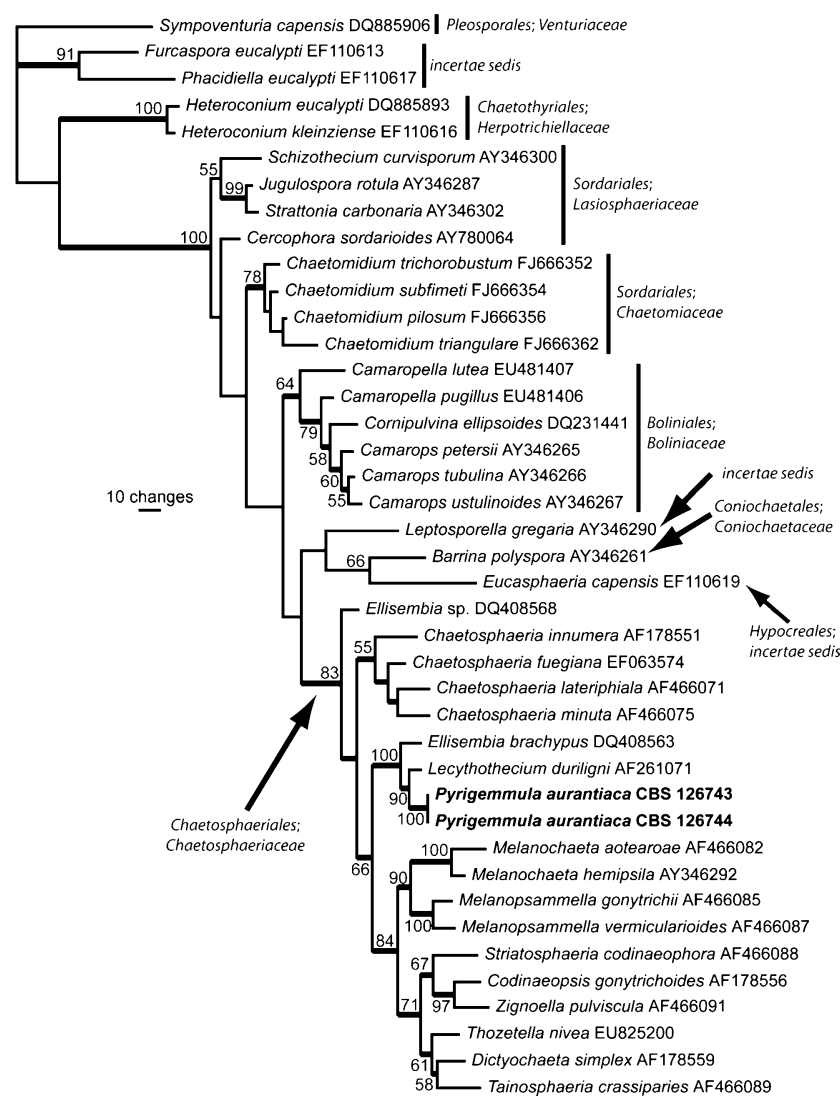

Fig. 1 The first of five equally most parsimonious trees obtained from a heuristic search with 100 random taxon additions of the LSU sequence alignment. The bootstrap support values from 1,000 replicates are shown at the nodes. Novel sequences generated for this study are shown in bold. Branches present in the strict consensus tree are thickened. The tree was rooted to a sequence of Sympoventuria capensis (GenBank accession DQ885906) 
Mycelium hyalinum, tenuitunicatum, pauciseptatum, rarium ramosum rarium anastomosum. Conidiophora rara, hyalina, curvata, tenuitunicata, demum bifurcata. Cellula conidiogena sessilis in hyphis, rara in conidiophoris, terminalis, aurantiaca, ovoidea, pyriformis, rara sphaerica vel cylindrical; hilum terminale, solitarium, inclusum; abseque isthmo. Conidia solitaria, ellipsoidea, tenuitunicata, distoseptata, castanea, eguttulata; hilum inclusum. Hypha germinalis terminalis, hyalina, guttulata, recta, demum bifurcata; leniter crescens.

\section{Typus Pyrigemmula aurantiaca}

Hyphae hyaline, thin-walled, straight, rarely branched at acute or right angles, sometimes with anastomoses. Conidiogenous cell usually arising directly from hyphae or rarely from delicate conidiophores. Conidiophores (when present) slightly curved as acute-angled projection from hypha, hyaline and thin-walled. Conidiogenous cell terminal, brown, narrow ovoid, pyriform, rarely spherical or short-filamentous; pore terminal, solitary; hilum flush, not thickened, not exerted, without isthmus. Conidia solitary, short to long ellipsoidal, thin-walled, distoseptate, reddish brown, eguttulate; hilum inconspicuous, internal, not flush or exserted (atrium type of Alcorn 1983, p. 50, figs 43, 4548). Germination axial from each pole with one hyaline, guttulate, straight hypha that later branches dichotomously. Germination evident after 2 days; germ tube growth slow, $90-150 \mu \mathrm{m}$ in 6 days. Surface of the colony a golden, powdery mass of conidia and conidiogenous cells. To the naked eye, the thin hyaline surface hyphae are not evident.

Pyrigemmula aurantiaca D. Magyar \& R. Shoemaker, sp. nov. Figs. 2, 3 and 4

MycoBank MB 517031

Etymology: aurantiaca L. referring to the golden or orange colour of the conidiogenous cells.

Hyphae pauci septatae $(15-20 \mu \mathrm{m})$. Conidiophora 3-5(10) $\times 2-3 \mu \mathrm{m}$ diam. Cellula conidiogena $6-14 \times 4-6 \mu \mathrm{m}$; hilum terminale ca. $2 \mu \mathrm{m}$ diam. Conidia $18-30 \times(5-) 8-$ $9 \mu \mathrm{m}, 0-5(-7)$ septata. Hypha germinales leniter crescens, $90-150 \mu \mathrm{m}$ in 6 deis.

Hyphae septate at $15-20 \mu \mathrm{m}$. Conidiophores ca. $3-5 \times 2-$ $3 \mu \mathrm{m}$, later extending to ca. $10 \times 3 \mu \mathrm{m}$ with a branch budding from the outside of the curvature, finally branching bifurcately to produce 4 or 5 cells. Conidiogenous cells $(9.6-) 11(-14.4) \times(4.8-) 5.7(-7.2) \mu \mathrm{m}$, with one solitary terminal pore $2 \mu \mathrm{m}$ diam. Conidia (17.6-)22.4-24 $(-27.2) \times 6.5-8 \mu \mathrm{m}, 0-5(-7)$ septate.

Germination axial from each pole with one hyaline, guttulate, straight hypha that later branches dichotomously. Germination slow, after 2 days; germ tube growth slow, 90$150 \mu \mathrm{m}$ in 6 days. Surface of the colony a golden, powdery mass of conidia and conidiogenous cells. The thin, hyaline
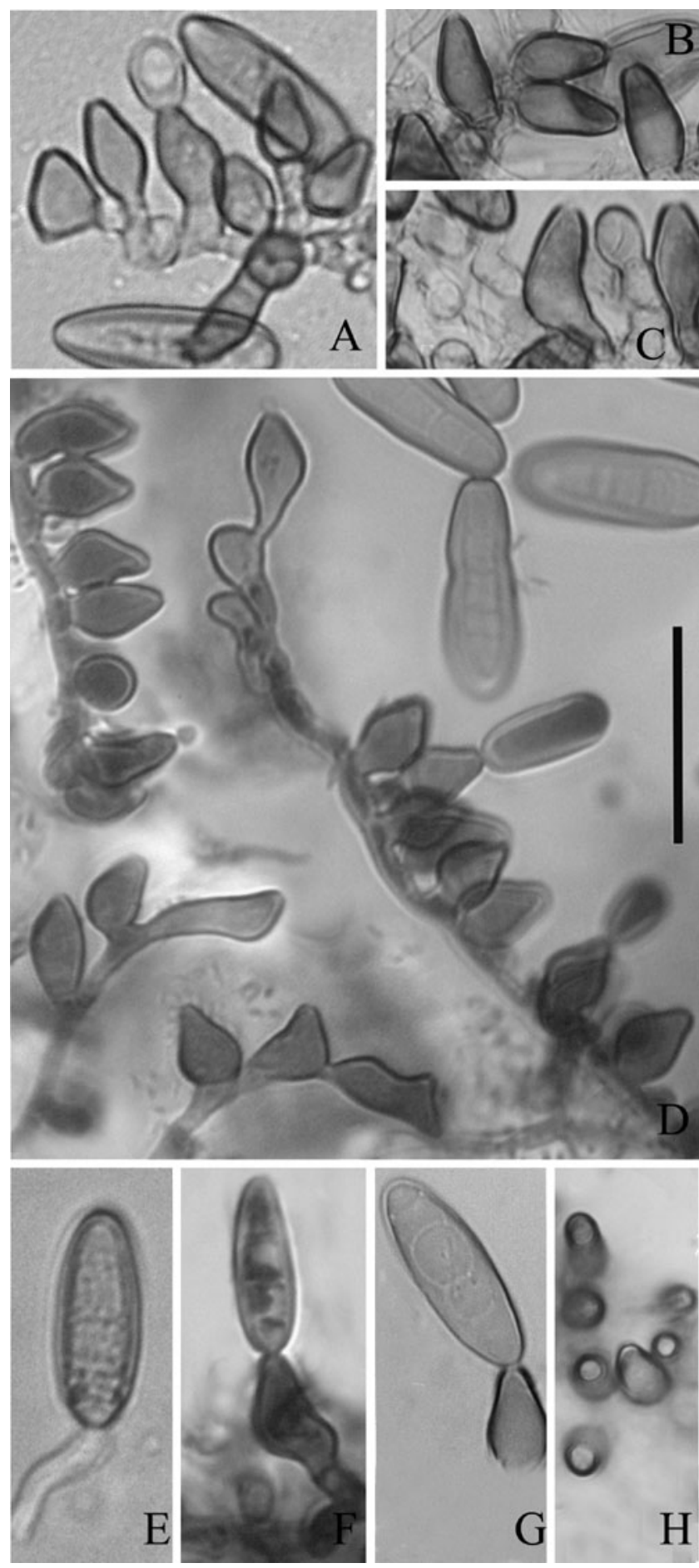

Fig. 2 Pyrigemmula aurantiaca. a-d Solitary and clustered conidiogenous cells. e Conidium germinated after 6 days on SNA. f,g Conidia prior to detachment. h Conidiogenous cell hilum. Scale bar $20 \mu \mathrm{m}$

surface hyphae are hardly visible. Colonies on MEA greyish brown, slimy, pulvinate, consisting of a cortical layer, at the margins lobed, slow growing, attaining $5 \mathrm{~mm}$ diam in 7 days (Figs. 2, 3 and 4). The colony brownish in reverse. On MEA, the fungus does not sporulate, the isolate 


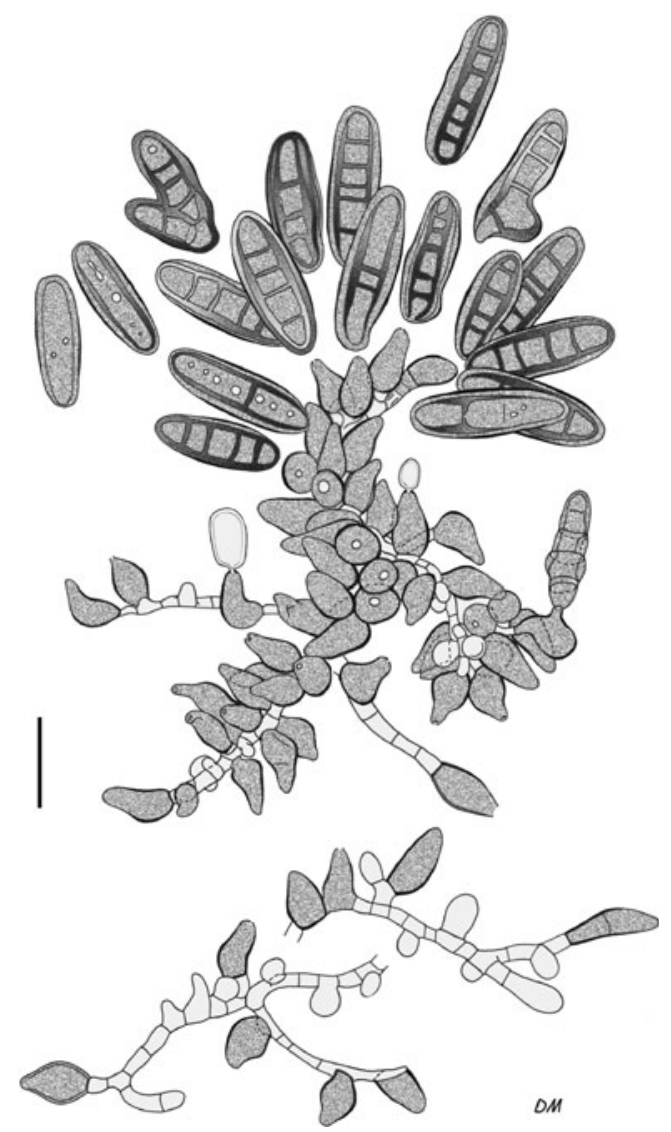

Fig. 3 Pyrigemmula aurantiaca conidiogenous cells and conidia. Scale bar $20 \mu \mathrm{m}$

sporulated when transferred to filter paper and sterilised bark (isolates from Vitis were transferred to Elaeagnus bark and vice versa). Filter paper, SNA and bark cultures do not differ in morphological characters from those of herbarium material.

Holotype Hungary, Noszvaj, on cortex of Vitis vinifera L., 22 Nov. 2009, D. Magyar, BP 101176, culture ex-type CBS 126743.

Additional specimens examined. Bark samples were collected in different sites in Hungary from the marginal surface of the bark of living Acer saccarinum L. (1 sample), Betula pendula Roht. (2 samples), Elaeagnus angustifolia L. (6 samples), Mespilus germanica L. (1 sample), Quercus sp. (1 sample), Platanus hybrida Brot. (6 samples), Pyrus communis L. (1 sample), Vitis vinifera L. (2 samples) and on litter (1 sample). Near the stream Szén-patak, Mountain Börzsöny, on litter (possibly Fagus sylvatica L.), 14 Feb. 1981, Á. Révay and J. Gönczöl (BP 11/23 and BP 11/24 as

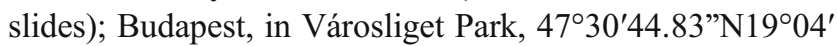
58.73”E, on Quercus sp., 20 Nov. 2006, D. Magyar (T09/ 10 as slide); Szokolya, $47^{\circ} 51^{\prime} 54.67^{\prime \prime} \mathrm{N}, 19^{\circ} 00^{\prime} 21.87^{\prime \prime} \mathrm{E}$, on M. germanica, 20 Jan. 2007, D. Magyar (T09/5 as slide); Budapest, Nagyvárad square, $47^{\circ} 28^{\prime} 42.33^{\prime \prime} \mathrm{N}, 19^{\circ} 05^{\prime} 24.95^{\prime \prime}$ E, on A. saccharinum, 12 Nov. 2009, D. Magyar (T62/3
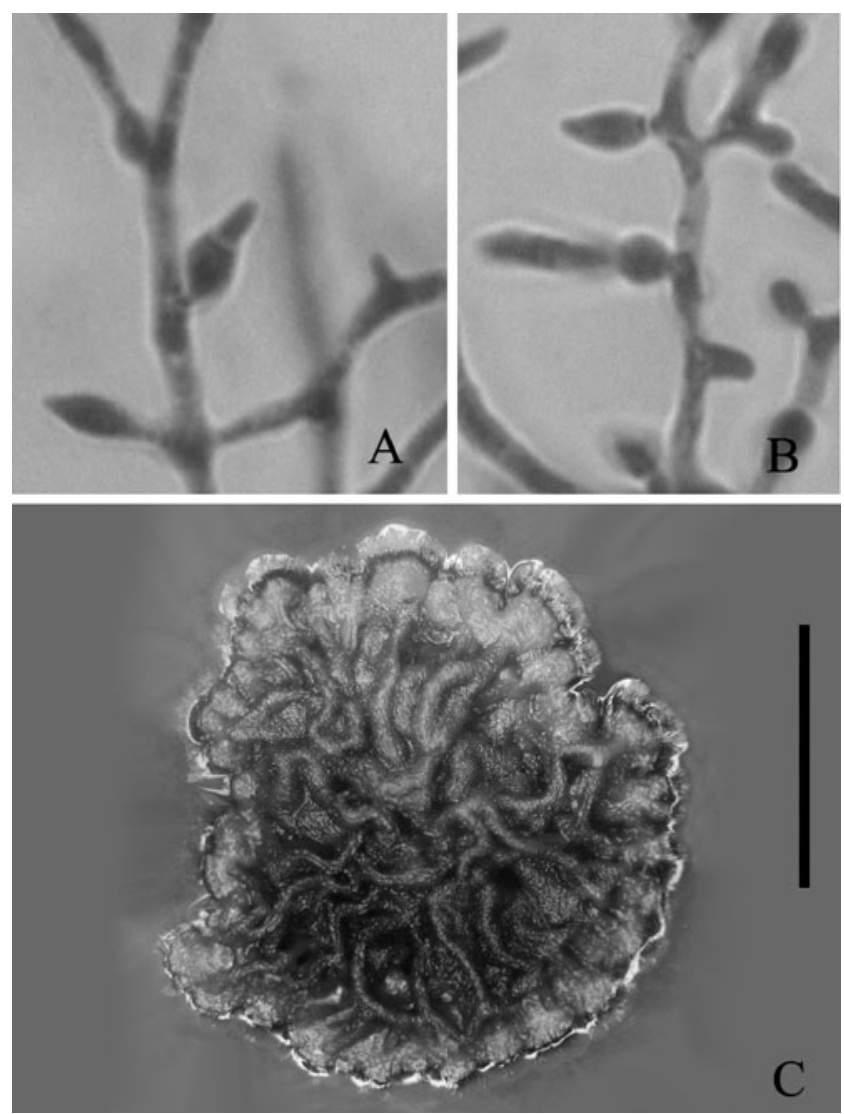

Fig. 4 Pyrigemmula aurantiaca on MEA. a,b Sterile hyphae. c Colony after 40 days of incubation. Scale bars (a,b) $20 \mu \mathrm{m},(\mathbf{c})$ $15 \mathrm{~mm}$

and T63/1 as slide, Tk0911/1 as bark sample); Budapest, Nagyvárad square, on B. pendula, 11 Dec. 2009, D. Magyar (CBS 126744 as MEA culture, GenBank accession number HM241693, T63/1 and T62/5 as slide, T160 as MEA culture); Budapest, Korong str., on B. pendula, 26 Nov. 2009, D. Magyar (T62/5, T63/2 and T63/4 as slide); Budapest, in the park of the Plant Protection Institute, $47^{\circ}$ $30^{\prime} 50.75^{\prime \prime} \mathrm{N}, 19^{\circ} 00^{\prime} 39.28^{\prime \prime} \mathrm{E}$, on E. angustifolia, 09 May 2007, D. Magyar (BP 99816 as slide, T09/1 as bark sample, DAOM 239578 as dried SNA culture); Pákozd, Isle Szúnyog-sziget, $47^{\circ} 12^{\prime} 37.03^{\prime \prime} \mathrm{N}, 18^{\circ} 34^{\prime} 30.39^{\prime \prime} \mathrm{E}$, on $E$. angustifolia, 04 July 2007, D. Magyar (T09/2 as slide); Belsőbáránd, by the side of the watercourse DinnyésKajtori-csatorna, $47^{\circ} 05^{\prime} 56.04^{\prime \prime} \mathrm{N}, 18^{\circ} 30^{\prime} 48.60^{\prime \prime} \mathrm{E}$, on $E$. angustifolia, 07 Aug. 2007, D. Magyar (T09/3 as slide); between Tinnye and Perbál, on E. angustifolia, 26 May 2008, É. Szita (T09/11 as slide); Kecskemét, Új-Városföld, $46^{\circ} 52^{\prime} 11.85^{\prime \prime} \mathrm{N}, 19^{\circ} 42^{\prime} 11.37^{\prime \prime} \mathrm{E}$, on E. angustifolia, 19 Sept. 2008, D. Magyar (T09/12 as slide); Visegrád, on E. angustifolia, 12 May 2010, D. Magyar (Tk1005/1 as bark sample); Budapest, in Városliget Park, $47^{\circ} 31^{\prime} 00.15^{\prime \prime} \mathrm{N}, 19^{\circ}$ $05^{\prime} 08.48^{\prime \prime} \mathrm{E}$, on P. hybrida, 11 July 2009, D. Magyar (T09/ 21a as slide); Budapest, in Városliget Park, on P. hybrida, 


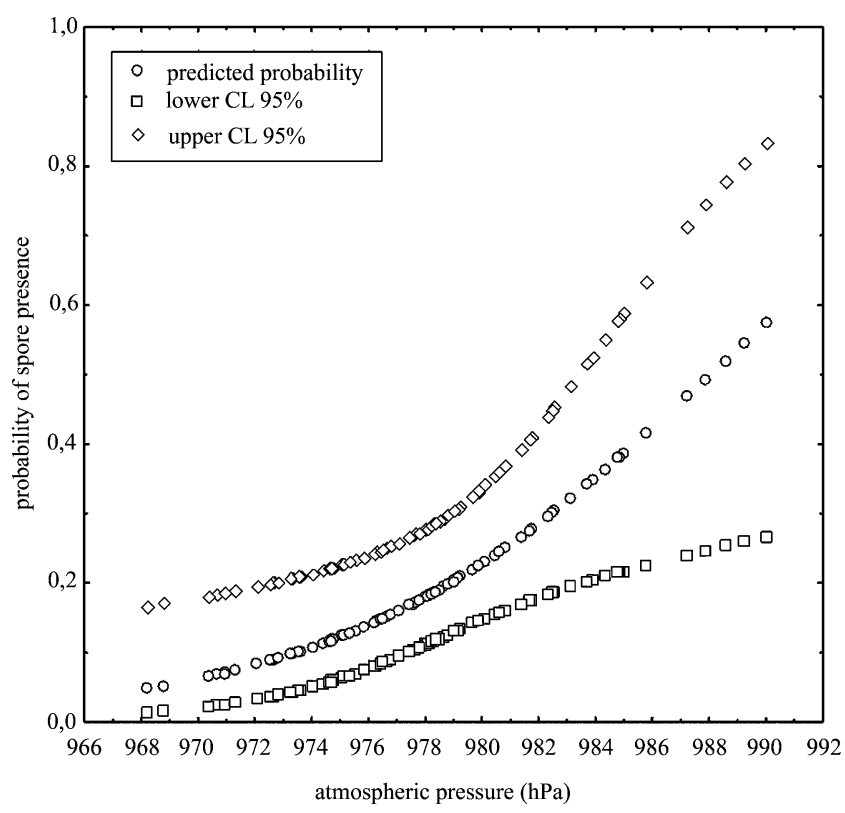

Fig. 5 Prediction model showing the increasing probability of the presence of Pyrigemma aurantiaca spores in air samples caused by an increase in atmospheric pressure.

26 Oct. 2009, D. Magyar (T09/21b as bark sample); Göd, $47^{\circ} 42^{\prime} 58.46^{\prime \prime} \mathrm{N}, 19^{\circ} 08^{\prime} 03.18^{\prime \prime} \mathrm{E}$, on P. hybrida, 27 Oct. 2009, D. Magyar (BP 100757 as bark sample); Budapest, in the park of the National Center for Epidemiology, on $P$. hybrida, 09 Feb. 2009, D. Magyar (T09/23 as slide); Budapest, in the courtyard of the Hungarian Natural History Museum, on P. hybrida, 10 Feb. 2009, Á. Révay and J. Gönczöl (BP 100758 as bark sample); Budapest, near Zugló train station, on P. hybrida, 01 Jun. 2010, D. Magyar (T81/1 as slide); Budapest, Lörinc, on P. communis, 08 Oct. 2008, J. Gönczöl (BP 100337 as bark sample); Budapest, in the park of the Plant Protection Institute, $47^{\circ} 30^{\prime} 50.51^{\prime \prime} \mathrm{N}$, $19^{\circ} 00^{\prime} 43.08^{\prime \prime} \mathrm{E}$, on $V$. vinifera, 07 Nov. 2007, D. Magyar (BP 99817 and T09/4 as slides); Noszvaj, 47 $56^{\prime} 36.51^{\prime \prime} \mathrm{N}$, $20^{\circ} 28^{\prime} 19.51^{\prime \prime} \mathrm{E}$, on $V$. vinifera, 22 Nov. 2009, D. Magyar (BP 101176 as bark sample, CBS 126743 as MEA culture, GenBank accession number HM241692, T161 as MEA culture, T62/4 as slide, Tk0911/2 as bark sample).

Notes.Pyrigemmula aurantiaca clustered close to sequences of Ellisembia brachypus and Lecythothecium duriligni. Ellisembia brachypus is distinct by having solitary, septate conidiophores and rostrate conidia, while the anamorph of $L$. duriligni also has solitary, septate conidiophores (Réblová and Winka 2001), thus being morphologically distinct. Pyrigemmula was further contrasted with the type species of the following genera of hyphomycetes. Murogenella, typified by M. terrophila, has hypha-like conidiogenous cells, and the conidia have a broad truncate basal cell. Bactrodesmiastrum, typified by $B$. obscurum, has flask-shaped conidiogenous cells with a truncate apex, and the conidia are obovoid, versicoloured, and have a truncate exserted hilum. Janetia, typified by $J$. euphorbiae, has conidiogenous cells with one to several truncate openings, and the conidia have a truncate base. The monograph of Janetia by Goh and Hyde (1996) treated 17 species, and emended the description of the genus. However, the 17 species treated all had denticulate conidiogenous cells and the conidia exhibited a conspicuous, exerted truncate base quite unlike the comparable structures of $P$. aurantiaca. Phragmospathula, typified by P. phoenicis, has obovoid conidiogenous cells that proliferate and bear conidia that have a spathulate basal cell. Heteroconium, typified by $H$. citharexyli, has more elaborate filamentous conidiophores and conidia with eusepta and a truncate base. The recently introduced genus Houjia is morphologically similar to Pyrigemmula, in having conidiophores reduced to conidiogenous cells, and solitary, brown, scolecosporous conidia. However, it has euseptate conidia, and is a member of the Capnodiales (Yang et al. 2010), whereas Pyrigemmula is a member of the Chaetothyriales.

Pyrigemmula aurantiaca spores were found in stemflow samples draining from Alnus glutinosa (23 Feb. 2004), Carpinus betulus (12 Jan. 2004), Celtis occidentalis, Crataegus monogyna (29 July 2003), and Cercis siliquastrum (30 July 2003). In water-filled maple tree hollows, spores were found in low concentrations, but occurred throughout the year during the 5-year long observation period (samples v25, v20, v3, v5, respectively; preserved on slides).

Free spores of $P$. aurantiaca were also observed in saphoney samples (1-2 spores/10 g), but only in those of honeydew origin (often called as 'forest honey') or Castanea honeys, which were contaminated with honeydew (m20326, from Abies sp., Italy; m21884, unspecified forest honey, Lazio, Italy; m21888, unspecified forest honey, Friuli Venezia Giulia, Italy; m21892, honeydew honey from Abies alba Mill., Italy; m20406 and m20409, honeys from Castanea sativa Mill., Italy; m21935, unspecified forest honey, Toscana, Italy; m21639 and m30093, unspecified forest honeys, Liguria, Italy; m00025, unspecified forest honey, Ózd, Hungary; m00026, unspecified forest honey, Croatia; m00028, unspecified forest honey, Slovakia). Spores were absent, however, from floral honeys.

Air samplers caught these spores only sparsely both in Italy and Hungary. The airborne concentration of the fungus fluctuated between $0-3 \mathrm{spores} / \mathrm{m}^{3}$, Logit regression analysis performed on airborne spore data showed that atmospheric pressure had significant effect $(p=0.009)$. Temperature and rain, having no significant effects, were excluded from the model. The prediction of the probability of the presence of $P$. aurantiaca spores in air samples is 
depicted in Fig. 5. The amount of increase of such probability corresponds with the calculated odds ratio (1.162, lower CL 95\% 1.038, upper CL 95\% 1.302), which implies that by $1 \mathrm{hPa}$ increase of the atmospheric pressure the presence of spores is 1.162 times more likely.

\section{Discussion}

The finding that $P$. aurantiaca could occur in the inner bark or bark fissures of grapevines and a variety of other woody hosts, is not that surprising. This phenomenon could be more common among ascomycetes than previously accepted, as several phytopathogenic species of the Botryosphaeriaceae, Calosphaeriaceae, Togniniaceae, etc. have been shown to migrate from branches and stems of grapevines and fruit trees to other woody hosts in the immediate vicinity (Crous et al. 2006b; Damm et al. 2007). According to Kubátová et al. (2004), some species of Phaeoacremonium could be dispersed between woody hosts by bark beetles, as they have also been isolated from these vectors. Based on the results obtained in this study, $P$. aurantiaca appears to lack host specificity, and currently there is also no indication what ecological role it plays, nor if it could be pathogenic to any of these hosts.

The low frequency and concentration (0-3 spores $\left./ \mathrm{m}^{3}\right)$ of $P$. aurantiaca spores in the air samples suggests that this fungus is rarely dispersed by wind. The conditions for wind dispersal for this fungus living in the inner marginal surface of the bark are poor, because the air may be still inside these fissures (Gregory 1961). Deposits of free spores were often observed inside the bark fissures and probably were carried there by stem-flow rainwater (Magyar 2008). It is hypothesised that stem-flow may play an important role providing microscale dispersal between fissures. Spores carried by stem-flow are trapped and accumulated in the fissures, thus the fungus could colonise new fissures in the bark.

Furthermore, these data suggests that the spores of $P$. aurantiaca are frequent in South and Central Europe in forest- and honeydew honeys, as well as in Castanea honeys. Honeydew, a product of piercing insects feeding on the trees are harvested and transported by honeybees to the hives and processed into honeydew honey. Honeys from silver-fir, oak-trees, etc. are marketed worldwide and often called "forest honey". Therefore, these honeys were in contact with tree bark, and essentially act as a conidial trap (Magyar et al. 2005).

Pyrigemmula represents yet another novel genus of hyphomycetes from the inner bark of woody hosts like Phaeomoniella, Phaeoacremonium and Collophora (Mostert et al. 2006; Damm et al. 2010). The fact that so many novel genera are currently being recorded from unusual substrates such as fruit surfaces (Batzer et al. 2008; Frank et al. 2010; Yang et al. 2010), stem-sap and bark, leaf trichomes (Dornelo-Silva and Dianese 2004), extremotolerant environments (Selbmann et al. 2008) rocks (Gueidan et al. 2008; Ruibal et al. 2008, 2009), endophytes (Strobel and Daisy 2003), intestinal tracks of insects (Suh et al. 2005), suggests that mycologists have just been scratching the surface and sampling obvious habitats when looking at fungal diversity. New DNA sequencing technologies that are able to detect obscure and frequently non-cultivatable taxa, will further highlight the inability of presently employed techniques to collect and assist in describing the fungal biodiversity currently expected to exist (Hibbett et al. 2009). This fully underlines the need for a novel approach to dealing with the magnitude of undescribed biodiversity in Kingdom Fungi.

Acknowledgements The authors are grateful to Drs Ágnes Révay, and János Gönczöl, Hungarian Natural History Museum, Budapest, and Éva Szita, Plant Protection Institute of the Hungarian Academy of sciences, Budapest, for the collection of the fungus (BP 11/23, BP 11/ 24, BP 100337, BP 100758 and T09/11), and for Francesca Grillenzoni, National Institute for Apiculture, Bologna, for providing honey samples. This work was supported by the grant OTKA F67908.

Open Access This article is distributed under the terms of the Creative Commons Attribution Noncommercial License which permits any noncommercial use, distribution, and reproduction in any medium, provided the original author(s) and source are credited.

\section{References}

Alcorn JL (1983) Generic concepts in Drechslera, Bipolaris and Exserohilum. Mycotaxon 17:1-86

Batzer JC, Mercedes Diaz Arias M, Harrington TC, Gleason ML, Groenewald JZ, Crous PW (2008) Four species of Zygophiala (Schizothyriaceae, Capnodiales) are associated with the sooty blotch and flyspeck complex on apple. Mycologia 100:246258

Crous PW, Gams W, Stalpers JA, Robert V, Stegehuis G (2004) MycoBank: an online initiative to launch mycology into the 21st century. Stud Mycol 50:19-22

Crous PW, Groenewald JZ, Risède J-M, Simoneau P, Hyde KD (2006a) Calonectria species and their Cylindrocladium anamorphs: species with clavate vesicles. Stud Mycol 55:213-226

Crous PW, Slippers B, Wingfield MJ, Rheeder J, Marasas WFO, Philips AJL, Alves A, Burgess T, Barber P, Groenewald JZ (2006b) Phylogenetic lineages in the Botryosphaeriaceae. Stud Mycol 55:235-253

Crous PW, Groenewald JZ, Summerell BA, Wingfield BD, Wingfield MJ (2009a) Co-occurring species of Teratosphaeria on Eucalyptus. Persoonia 22:38-48

Crous PW, Verkley GJM, Groenewald JZ, Samson RA (eds) (2009b) Fungal Biodiversity. CBS Laboratory Manual Series $1: 1-269$

Damm U, Crous PW, Fourie PH (2007) Botryosphaeriaceae as potential pathogens of Prunus in South Africa, with descriptions of Diplodia africana and Lasiodiplodia plurivora sp. nov. Mycologia 99:664-680 
Damm U, Crous PW, Fourie PH (2008a) A fissitunicate ascus mechanism in the Calosphaeriaceae, and novel species of Jattaea and Calosphaeria on Prunus wood. Persoonia 20:39-52

Damm U, Verkley GJM, Crous PW, Fourie PH, Haegi A, Riccioni L (2008b) Novel Paraconiothyrium species on stone fruit trees and other woody hosts. Persoonia 20:9-17

Damm U, Fourie PH, Crous PW (2010) Coniochaeta (Lecythophora), Collophora gen. nov. and Phaeomoniella species associated with wood necroses of Prunus trees. Persoonia 24:60-80

Dornelo-Silva D, Dianese JC (2004) New hyphomycete genera on Qualea species from the Brazilian cerrado. Mycologia 96:879884

Essakhi S, Mugnai L, Crous PW, Groenewald JZ, Surico G (2008) Molecular and phenotypic characterisation of novel Phaeoacremonium species isolated from esca diseased grapevines. Persoonia 21:119 134

Frank J, Crous PW, Groenewald JZ, Oertel B, Hyde KD, Phengsintham P, Schroers HJ (2010) Microcyclospora and Microcyclosporella: novel genera accommodating epiphytic fungi causing sooty blotch on apple. Persoonia 24:93-105

Goh T-K, Hyde KD (1996) Janetia curviapicis, a new species, and an emended description of the genus. Mycologia 88:1014-1021

Gregory PH (1961) The microbiology of the atmosphere. Interscience, London

Gueidan C, Ruibal Villaseñor C, de Hoog GS, Gorbushina AA, Untereiner WA, Lutzoni F (2008) A rock-inhabiting ancestor for mutualistic and pathogen-rich fungal lineages. Stud Mycol 61:111-119

Hibbett DS, Ohman A, Kirk PM (2009) Fungal ecology catches fire. New Phytol 184:279-282

Hirst JM (1952) An automatic volumetric spore trap. Ann Appl Biol $39: 257-265$

Ingold CT (1975) An illustrated guide to aquatic and water-borne hyphomycetes. Fungi Imperfecti with notes on their biology. FBA Sci Pub 30:1-96

Kubátová A, Kolarík M, Pazoutová S (2004) Phaeoacremonium rubrigenum - hyphomycete associated with bark beetles found in Czechia. Folia Microbiol 49:99-104

Louveaux J, Maurizio A, Vorwohl G (1978) Methods of melissopalynology. Bee World 59:139-157

Magyar D (2008) The tree bark: a natural spore trap. Asp Appl Biol $89: 7-16$

Magyar D, Gönczöl J, Révay Á, Grillenzoni F, Seijo-Coello MDC (2005) Stauro- and scolecoconidia in floral and honeydew honeys. Fung Div 20:103-120

Magyar D, Frenguelli G, Bricchi E, Tedeschini E, Csontos P, Li DW, Bobvos J (2009) The biodiversity of air spora in an Italian vineyard. Aerobiologia 25:99-109

Mostert L, Groenewald JZ, Summerbell RC, Robert V, Sutton DA, Padhye AA, Crous PW (2005) Species of Phaeoacremonium associated with human infections and environmental reservoirs in infected woody plants. J Clin Microbiol 43:1752-1767

Mostert L, Groenewald JZ, Summerbell RC, Gams W, Crous PW (2006) Taxonomy and pathology of Togninia (Diaporthales) and its Phaeoacremonium anamorphs. Stud Mycol 54:1-115

Phillips AJL, Alves A, Pennycook SR, Johnston PR, Ramaley A, Akulov A, Crous PW (2008) Resolving the phylogenetic and taxonomic status of dark-spored teleomorph genera in the Botryosphaeriaceae. Persoonia 21:29-55

Rayner RW (1970) A mycological colour chart. CMI and British Mycological Society, Kew, Surrey, England
Réblová M, Winka K (2001) Generic concepts and correlations in ascomycetes based on molecular and morphological data: Lecythothecium duriligni gen. et sp. nov. with a Sporidesmium anamorph, and Ascolacicola austriaca sp. nov. Mycologia 93:478-493

Rehner SA, Samuels GJ (1994) Taxonomy and phylogeny of Gliocladium analysed from nuclear large subunit ribosomal DNA sequences. Mycol Res 98:625-634

Ruibal C, Platas G, Bills GF (2008) High diversity and morphological convergence among melanised fungi from rock formations in the Central Mountain System of Spain. Persoonia 21:93-110

Ruibal C, Gueidan C, Selbmann L, Gorbushina AA, Crous PW, Groenewald JZ, Muggia L, Grube M, Isola D, Schoch CL, Staley JT, Lutzoni F, de Hoog GS (2009) Phylogeny of rock-inhabiting fungi related to Dothideomycetes. Stud Mycol 64:123-133

Schoch CL, Crous PW, Groenewald JZ, Boehm EWA, Burgess TI, de Gruyter J, de Hoog GS, Dixon LJ, Grube M, Gueidan C, Harada Y, Hatakeyama S, Hirayama K, Hosoya K, Hyde KD, Jones EBG, Kohlmeyer J, Li YM, Kruys Å, Lücking R, Lumbsch HT, Lutzoni F, Marvanová L, McVay AH, Mbatchou JS, Miller AN, Mugambi GK, Muggia L, Nelsen MP, Nelson P, Owensby CA, Li YM, Phillips AJL, Phongpaichit S, Pointing SB, PujadeRenaud V, Raja HA, Rivas Plata E, Robbertse B, Ruibal C, Sakayaroj J, Sano T, Selbmann L, Shearer CA, Shirouzu T, Slippers B, Suetrong S, Tanaka K, Volkmann-Kohlmeyer B, Wingfield MJ, Wood AR, Woudenberg JHC, Yonezawa $\mathrm{H}$, Zhang Y, Spatafora JW (2009) A class-wide phylogenetic assessment of Dothideomycetes. Stud Mycol 64:1-15

Selbmann L, de Hoog GS, Zucconi L, Isola D, Ruisi S, Gerrits van den Ende AHG, Ruibal C, De Leo F, Urzì C, Onofri S (2008) Drought meets acid: three new genera in a dothidealean clade of extremotolerant fungi. Stud Mycol 61:1-20

Slippers B, Smit WA, Crous PW, Coutinho TA, Wingfield BD, Wingfield MJ (2007) Taxonomy, phylogeny and identification of Botryosphaeriaceae associated with pome and stone fruit trees in South Africa and other regions of the world. Plant Pathol $56: 128-139$

Strobel G, Daisy B (2003) Bioprospecting for microbial endophytes and their natural products. Microbiol Mol Biol Rev 67:491-502

Suh S-O, McHugh JV, Pollock D, Blackwell M (2005) The beetle gut: a hyperdiverse source of novel yeasts. Mycol Res 109:261-265

Swofford DL (2003) PAUP*. Phylogenetic analysis using parsimony (* and their methods). Version 4.0b.10. Sinauer, Sunderland

Van Niekerk JM, Crous PW, Groenewald JZ, Fourie PH, Halleen F (2004) DNA phylogeny and morphological characterization of Botryosphaeria species occurring on grapevines. Mycologia 96:781-798

White TJ, Bruns T, Lee J, Taylor J (1990) Amplification and direct sequencing of fungal ribosomal RNA genes for phylogenetics. In: Innis MA, Gelfand DH, Sninsky JJ, White TJ (eds) PCR protocols: a guide to methods and applications. Academic, San Diego, pp 315-322

Yang HL, Sun GY, Batzer JC, Crous PW, Groenewald JZ, Gleason ML (2010) Novel fungal genera and species associated with the sooty blotch and flyspeck complex on apple in China and the USA. Persoonia 24:29-37

Zhang Y, Schoch CL, Fournier J, Crous PW, de Gruyter J, Woudenberg JHC, Hirayama K, Tanaka K, Pointing SB, Spatafora JW, Hyde KD (2009) Multi-locus phylogeny of Pleosporales: a taxonomic, ecological and evolutionary reevaluation. Stud Mycol 64:85-102 